\title{
PARTNERSHIP BETWEEN GOVERNMENT AND PRIVATE VOCATIONAL SCHOOL IN PUBLIC SERVICES \\ (Study at the Village Fishermen Filling Station Sumber Jaya Sub-District of Kampung Melayu City of Bengkulu)
}

\author{
Novliza Eka Patrisia, University of Muhammadiyah Bengkulu \\ Rekho Adriadi, University of Muhammadiyah Bengkulu \\ Study Program of State Administration of FISIP UMB \\ Email: novlizaekap@umb.ac.id
}

\begin{abstract}
Partnerships between Government and the Private Sector in Public Services. Quality of public services will result in a positive response from the public so it needs a specific strategy in its implementation, one of which is by using Public Private Partnership (PPP). This study aims to describe and analyze the partnership that exists between the government and the private sector, describe and analyze the public response to the quality of service as well as explain the enabling and inhibiting factors in the implementation of public service in Fuel Filling Station of Fishermen (SPBN) Kampung Bahari, of Bengkulu city. The method used in this study used a qualitative approach. Quality of public services in SPBN Kampung Bahari get an appraisal "Good" of users but in terms of access and tangible gain diverse assessment due to locations that are not easily accessible by all users and the number of facilities SPBN that were in poor condition.
\end{abstract}

Keywords: public services, public private partnership, SPBN

\section{Preliminary}

Indonesia is a country that adheres to the basis of social welfare in accordance with what is stated in the Preamble to the 1945 Constitution which mandates that the purpose of the State of the Republic of Indonesia be established, among others, to promote the general welfare and educate the life of the nation. The mandate implies that the State of Indonesia is obliged to improve the lives of every citizen / community through a system of government that supports the creation of quality public services in order to fulfill the needs of the community to achieve a prosperity.

There are many factors that cause public services in Indonesia to be unable to fulfill the wishes of the community, including the lack of infrastructure for public service goods and services. In the service of public goods for example, the Central Government through the Ministry of Energy and Mineral Resources (ESDM) together with PT. Pertamina (Persero) in order to provide excellent service for the fishing community has made the program of establishing a Fishermen Filling Station (SPBN), the aim is that the fuel subsidy in the form of diesel fuel can be properly distributed to fishermen and ensure fishermen to always get fuel supply without having to fight with land vehicle users who buy diesel fuel at the General Fuel Filling Station (SPBU). However, the number of SPBN in various regions is still lacking when compared to the needs of fishermen so that public services are not carried out properly because the fishermen are still having difficulties in obtaining diesel fuel.

The fisheries and marine sector is one of Indonesia's mainstay sectors. More than 2 (two) million fishermen and 10 (ten) million Indonesian citizens depend their lives on the abundance of fish in the archipelago (www.menkokesra.go.id).

Based on the data above, the fisheries and maritime sector is a potential economic potential of the State of Indonesia and has an extraordinary economic effect for millions of Indonesian citizens so that the Government of the Republic of Indonesia needs to provide special services for citizens who depend on the sector for their lives. 
As an effort to provide public services for fishermen, the Bengkulu City Government represented by Regionally Owned Enterprises (BUMD), namely Regional Enterprises "Aneka Usaha" (PDAU) also implemented the program. The steps taken by the City of Bengkulu Government are by establishing partnerships with the private sector, namely PT. Petronusa to provide services to fishermen in the city of Bengkulu.

The results of the partnership between Bengkulu City's "Various Business" (PDAU) Regional Company and PT. Petronusa is in the form of the establishment of a Fishermen's Fuel Filling Station (SPBN) located in the area of the Bahari Bahari Fish Auction Place (Kelurahan Kampung Kelaya), Sumber jaya Subdistrict, Kampung Melayu Subdistrict, Bengkulu City. The Bengkulu City Government's step in partnering with the private sector is a smart effort in the effort to implement quality public services. Because according to Uphof in (Hasbi, 2010), states that "To provide quality public services that require synergistic interaction of various actors or institutions that include the public sector (government), private (private) and civil society".

Based on the background described above, then the formulation of the problem in this study are: (1) What is the partnership that exists between the government and the private sector; (2) What is the response of the community to the quality of services provided; and (3) What are the supporting factors and obstacles to the implementation of public services at the Fishermen's Fuel Filling Station (SPBN) of Kampung Bahari, Sumber jaya Subdistrict, Kampung Melayu Subdistrict, Bengkulu City.

\section{Literature review}

1. Governance and Good Governance

According to Sumarto (2003), governance can be interpreted as "mechanisms, practices and citizens regulating resources and solving public problems". This is in line with the definition given by the United Nations Developments Program (UNDP) in Basuki (2006) which states that Governance is "the exercise of authority in the economic, political and administrative fields to manage various state affairs at every level and is a policy instrument country to encourage the creation of social cohesion ".

In terms of Good Governance, Basuki (2006) interpreted it as an effort to change the nature of the government (Government) which originally tended to work alone without regard to the aspirations of the community, to be an aspirational government. As with Basuki, Tjiptoherijanto (2010) defines Good Governance from the point of view of the expectations of the actors involved in decision making, stating that Good Governance is governance that seeks to meet the expectations of the parties involved in decision making.

With the involvement of stakeholders, decision making in public services will get careful consideration and all stakeholders' wishes will be achieved. The elements of Governance stakeholders according to Sjamsuddin (2006) include; individuals, organizations, institutions and social groups whose existence is very important for the creation of effective governance. These elements can be grouped into three parts, namely:

a) Country (State)

The definition of state / government (State) in this case generally covers all political institutions and the public sector. The role and responsibility of the state or government include the implementation of public services, the holding of power to govern, and building an environment that is conducive to the achievement of development goals at the local, national and international and global levels.

b) Private sector (Private sector)

Private sector actors include companies that are active in the interaction of market systems, such as: manufacturing, trade, banking and cooperatives, including informal 
sector activities. The role of the private sector is very important in the pattern of governance and development, because of its role as an opportunity to improve productivity, employment, sources of revenue, public investment, business development and economic growth.

c) Civil society

Civil society includes individuals and groups of people who interact socially, politically and economically. Civil society not only checks and balances the powers of government and the private sector but also contributes and strengthens the other two elements, such as helping to monitor the environment, depleting resources, pollution and social atrocities, contributing to economic development by helping to distribute the benefits of growth a more equitable economy in society, and offering opportunities for individuals to improve their living standards.

2. Public Services

Theoretically, Tjiptoherijanto (2010) states that public service is the management of the supply of goods / services directly or indirectly by the government to achieve social welfare in Pareto conditions. While Dwiyanto (2006) defines, public service is a series of activities carried out by the public bureaucracy to meet the needs of citizens and users. The statement is in line with Sinambela (2006) which states that public service is the fulfillment of the needs and needs of the community by state administrators.

Public services as a form of public goods provided by the government should be balanced with good service quality so that the public will put their trust in the government. In addition, according to Dwiyanto in (Hashim, 2006) quality public services are a strategic point to begin the development of Good Governance and to improve the quality of public services one way is to involve the interests of all elements of Governance.

As for measuring the quality of public services according to Zeithaml (Puspitosari, 2012) based on the following indicators:

a) Tangibles

This means that the quality of services in the form of office facilities, waiting rooms, and others.

b) Reliability

That is the ability and reliability to provide trusted services

c) Responsiveness

Namely the ability to help and provide services quickly and accurately, and responsive to consumer desires

d) Competence

That is the ability by service providers to convince and foster consumer confidence

e) Courtessy

Namely service providers must pay attention to norms and ethics that apply in order to provide a sense of comfort

f) Credibility

Public service providers must be trusted by the community in order to provide a sense of justice, satisfaction and information that can be accounted for

g) Security

A sense of security in various services to the community must be the main motto in the implementation of public services 
h) Access

Public services are actually services provided to all the general public until the rules limit it, so that public services must be easily accessible

i) Communication

Communication is the simplest tool in providing quality services. So that communication in service needs to be maintained and always open

j) Understanding

Public services must understand what the community wants. If public services are built based on understanding, then the service will be on target.

3. Partnership

According to Sulistyani in (Marsiatanti, 2011), partnership in etymological perspectives is adapted from the word Kemitraan and comes from the root word partner, which means "partner, partner, partner, or component". While the partnership is translated into partnership or partnership. Thus, partnership can be interpreted as a form of alliance between two or more parties that form a cooperative relationship on the basis of agreement and a sense of mutual need in order to improve capability in a particular business or specific purpose, so as to obtain better results. In the context of partnerships between the government and the private sector or the Public Private Partnership according to Mahmudi (2007), it is interpreted as a work unit of government service providers and government business units (BUMN / BUMD) that work together with the private sector and the third sector.

While Amirullah in (Irianti, 2011) stated, Public Private Partnership is a collaboration to give part of the government's authority to the private sector to carry out part or all of the development and or operation of infrastructure. Cooperation is a concept based on trust in a work team to achieve mutually beneficial goals between partner members where each partner always tries to resolve conflicts or procedural differences so that it will benefit each party.

As for the implementation model of Public Private Partnership, Savas dalam (Irianti, 2011) states that partnerships between the government and the private sector can be carried out with several concepts including fully public (full government) to fully private (full private).

4. Conceptual Framework

In this study, researchers used an analysis of the implementation model of the Public Private Partnership from E. Savas. While to measure the quality of public services in the object of this study, the authors use the service quality indicators expressed by Zeithaml, et all.

\section{Research Methods}

The research method used in this study is a descriptive method with a qualitative approach. As expressed by Moleong (2004) who argues that a qualitative approach is research that intends to understand the phenomenon of what is experienced by the subject of the study for example, behavior, perception, motivation, action, holistically, and by way of description in the form of words and language, in a special natural context and by using it as a natural method".

The location of this research is in the City of Bengkulu, while the research site is the Office of the Refueling Station for Fishermen (SPBN) Kampung Bahari Sumber Sumber Jaya 
Village, Malay Village District, Bengkulu City, Regional Office of "Various Businesses", Bengkulu City and PT. Petronusa in Bengkulu City.

Sources of data in this study were obtained through two sources, namely primary data sources and secondary data sources obtained by several data collection techniques, namely: interviews, observation and documentation. The research instrument used in this study was the researcher himself, interview guidelines, field notes.

While the method of data analysis used in this study is Interactive Model as expressed by Miles and Huberman (1992). This analysis technique consists of several components, namely data collection, data reduction, data presentation, and conclusion drawing.

\section{Discussion}

Partnership between the government and the private sector in the public service must be carried out proportionally, each actor involved needs to unite the power to achieve the goals that are partnered, namely in the form of quality public services.

a. Partnership Interacted between Government and Private in Organizing Public Services at the Fishermen's Refueling Station (SPBN) of Kampung Bahari, Sumber Jaya Village

In a partnership, there are at least two people or institutions (Stake-holders) involved. Whereas those involved in partnership in public services in SPBN Kampung Bahari are Regional Enterprises "Various Businesses" in Bengkulu City and PT. Petronusa.

Both stakeholders involved have different capacities so they can complement each other. The capacity of Regional Enterprises "Various Enterprises" Bengkulu City, namely: First, Is a company owned by the local government and if needed every year will get additional capital participation from the City Government of Bengkulu, Secondly, It has experience in the business world because it was established since January 14, 1969 ,

Third, has a varied business unit (trade, printing, workshop, agribusiness and nonbank financial services.

Fourth, has an adequate number of employees (62 employees). While the capacity owned by PT. Petronusa are: First, Experienced in terms of employment contracts with PT. Pertamina (Persero) because it was previously a Pertamina Asphalt agent and once managed a gas station. Second, have sufficient capital. Third, business management is neater and more effective in the use of human resources (HR).

In the partnership that exists, the two stakeholders both have tasks and roles that must be carried out. The concrete role of PT. Petronusa in establishing the SPBN Kampung Bahari, namely: First, the management of permits and administrative requirements. Second, include capital. PT. Petronusa also acts as the owner of capital in the establishment of the SPBN Kampung Bahari. So by sharing capital for the establishment of the SPBN Kampung SPBN between the Regional Enterprises "Various Enterprises" of Bengkulu City and PT. Petronusa both have an equal position in business control. Third, the person in charge of solar redemption, namely PT. Petronusa has a role to order solar from PT. Pertamina (Persero). This is because those who have power over the establishment of the SPBN from PT. Pertamina (Persero) is PT. Petronusa, so all SPBN administrative matters and data about SPBN are all in the name of PT. Petronusa, thus, who has access and authority to redeem diesel fuel to PT. Pertamina (Persero) is not the SPBN manager (Manager) but PT. Petronusa.

While the duties and role of Regional Enterprises "Various Enterprises" in the city of Bengkulu in the partnership are: First, the responsible SPBN Kampung Bahari operational, which is responsible for the implementation of the service process to fishermen starting 
Solar from Depo PT. Pertamina (Persero) came to report distribution results. Second, as the owner of a portion of business capital. So in establishing the SPBN Kampung Bahari, the business capital does not only come from one of the stakeholders but comes from the two stakeholders involved in the partnership.

As for knowing the partnership model between the government and the private sector that occurs in SPBN Kampung Bahari, it can be known by looking at the purpose of the partnership. In the case of partnerships that occur in SPBN Kampung Bahari, the purpose of the Bengkulu City Government instructs Regional Enterprises "Various Businesses" in Bengkulu City to partner with PT. Petronusa in order to provide fuel services for fishermen in the city of Bengkulu is to establish business relations between the government and the private sector, which hopes to increase local revenue (PAD) as well as hand over the affairs of public services which is actually the authority of the government to be the authority of the private sector.

The implementation model of the partnership above, if combined with the opinion of Savas in (Irianti, 201) is classified as a model of the Public Authority, namely: "The government is regarded as the owner of full authority over public services such as clean water, electricity, transportation and telecommunications services. For that, to maximize its performance, the government needs to partner with the private sector (private) so that its management prioritizes business relations rather than politics ".

b. Community Response to the Quality of Services Organized by the Fishermen's Refueling Station (SPBN) of Kampung Bahari, Sumber Jaya Village, Kampung Melayu Subdistrict, Bengkulu City.

SPBN Kampung Bahari is a business unit as well as a service unit founded on partnerships between the government and the private sector to provide quality fuel services for fishermen.

As for one of the steps used to find out the results of a partnership in the implementation of public services is to test it based on the opinions of the users of services related to the following service elements:

1. Tangibles are the quality of services in the form of office facilities, waiting rooms, and others. Physical facilities and facilities in the SPBN Kampung Bahari are complete but in a condition that is not intact. The SPBN building suffered a leak when the rain fell, the canopy roofs in the SPBN area were also damaged due to the beach winds and many iron material facilities were subjected to corrosion. However, based on interviews with users of their services, there are still facilities in the SPBN Kampung Bahari which claim to be good and comfortable. This is based on the habits of fishermen who are more concerned with the essence of service (fuel distribution) than the convenience of facilities.

2. Reliability is the ability and reliability to provide trusted services. Trusted services are a must for all sectors of public service. If the users have believed it, the satisfaction of the service users will increase. In the case of providing trust to the users of their services for the amount of fuel in the SPBN of the Bahari Village, the Industry and Trade Office routinely checks and inspects the measuring instruments used. In addition, the Department of Industry and Trade also routinely supervises the distribution of Subsidized Solar conducted by SPBN Kampung Bahari and journalists often cover Solar distribution activities at SPBN Kampung Bahari. Thus, fishermen who become SPBN service recipients strongly believe in the services provided by SPBN Kampung Bahari. 
3. Responsiveness is the ability to help and provide services quickly and accurately, and responsive to consumer desires. Kampung Bahari SPBN is considered very responsive by its service users, this is because the services provided are not convoluted and fast, so that when its service users boom in the afternoon, all can be served by the SPBN Kampung SPBN officers. Efforts made by the SPBN management of Kampung Bahari to improve service responsiveness are by removing the service requirements that should be applied to its service users, such as vessel documents or proof / sign of fishermen because officials at the SPBN have memorized the fishermen who often get their services .

4. Competence namely the ability of service providers to convince and foster consumer confidence. The competence of officers in SPBN Kampung Bahari, although there are only 2 officers who have an S1 certificate from a total of 8 officers, get a "Good" rating from the users of the service. The above is because the working hours of the officials in the SPBN Kampung Bahari are very high. All officers have worked for more than 1 year and have been very proficient in providing services. Service users can also be served well even at the height of the crowd.

5. Courtessy, namely service providers must pay attention to norms and ethics that apply in order to provide a sense of comfort. The officers in SPBN Kampung Bahari are all Javanese tribes and the majority are also served by Javanese, Bugis and Medan people. Thus having the same values and ethics so that in the implementation of the service will understand each other and understand how and what should be done by the service providers and recipients, and the recipients of Kampung Bahari SPBN services also state that aspects. Courtessy in SPBN Kampung Bahari is classified as "Good"

6. Credibility, namely the public service provider must be trusted by the community to provide a sense of justice, satisfaction and information that can be accounted for. Kredibilias SPBN Kampung Bahari received a "Good" rating from its service users. The assessment is because the Kampung Bahari SPBN Manager always tries to work according to the prevailing rules, which is only selling Solar to fishermen, not to other sectors, even though during bad weather there is not even one fisherman who uses the service.

7. Security, namely the sense of security in various services to the public must be the main motto in the implementation of public services. Security in organizing public services can be done in many ways, either using methods that rely on tools or rely on officers. Generally public facilities such as banks, supermarkets and stations in maintaining the security of their services involve security personnel or security guards. However, what is done by the SPBN management of Kampung Bahari is not the case. Kampung Bahari SPBN managers use local residents to be their security guards by recruiting influential people around the Kampung Bahari SPBN area to be recruited to become employees while aiming to maintain security. The result is that service users in the SPBN Kampung Bahari consider that transactions in SPBN Kampung Bahari are "very safe".

8. Access, public services are actually services provided to all the general public until the rules limit it, so that public services must be easily accessible. The current government regulation is that fishermen are required to buy Solar in SPBN, but in Bengkulu City there is only 1 unit of SPBN, namely SPB Kampung Bahari. This SPBN is located in the city of Bengkulu even though the fishermen in the city of Bengkulu are scattered throughout the coastal areas so that in terms of Access, the fishermen who use the SPBN Kampung Bahari services give mixed responses. The response from fishermen from 
Bengkulu City states, Kampung Bahari SPBN is very easy to access because the location is very strategic, but for fishermen from other Bengkulu City areas (especially the area of melted wells and zakat beach) consider that SPBN Kampung Bahari is very difficult access because of the very long distance.

9. Communication is the simplest tool in providing quality services. So that communication in service needs to be maintained and always open. Communication carried out by the service officers in the SPBN Kampung Bahari gets good value from the users of the service because the officers are very communicative and can familiarize themselves with the users of the service. However, the good communication is not matched by the use of adequate media so that it only relies on oral communication that only a few people can accept and respond to.

10. Understanding, Public services must understand what the community wants. If public services are built based on understanding, then the service will be on target. The efforts of SPB Kampung Bahari managers to understand the desires of users of their services have been very good. SPBN managers do not want their users to feel hampered to get services. When there are many service users lining up, managers try to understand it by allowing them to serve themselves because if they wait to be served by officers, the service will be slow. In addition, when the supply of diesel fuel is limited, the SPBN management also seeks to understand the desires of its service users by proportionally sharing the distributed fuel so that all service users are equally supplied with fuel for the purpose of fishing.

c. Supporting and Inhibiting Factors in Organizing Public Services at the Fishermen's Fuel Filling Station (SPBN) of Kampung Bahari, Sumber jaya Village, Kampung Melayu Subdistrict, Bengkulu City

In public services, there must be things that can support and hinder their implementation. The things that support and inhibit the implementation / implementation of public services in SPBN Kampung Bahari are as follows:

1. Supporting Factors Supporting factors for the implementation of public services in SPBN Kampung Bahari, namely; First, each stakeholder involved in the partnership has adequate capacity both in terms of capital and experience. Second, it is located in a strategic location, namely in the city area and close to the center of fishing activities, Third, the purchasing power of the people who always increases if the weather is normal and the catch is abundant. Fourth, the awareness of the fishermen of the function and purpose of the SPBN construction is to serve them so that they are enthusiastic to use SPBN Kampung Bahar services.

2. Inhibiting Factors Barriers experienced by SPB Kampung Bahari in public services are: First, Inadequate facilities due to many are damaged due to corrosion. Secondly, there are people who often rely on their vessels in the SPBN area so that ships that want to refuel BBM cannot directly reach the SPBN. Third, PT. Pertamina (Persero) related to the allocation of additional and reduced fuel quota. And Fourth, unfriendly weather conditions in December and January caused no fishermen to transact in the SPBN Kampung Bahari.

\section{Conclusion}

1. In a theoretical point of view, a partnership implementation model that exists between the Bengkulu City Government and PT. Petronusa is a Public Authority model, namely; In the case of partnerships that occur in SPBN Kampung Bahari, the purpose of the City of Bengkulu Government instructs Regional Companies "Aneka Usaha" to partner with PT. 
Petronusa in order to provide fuel services for the fishing communities in the city of Bengkulu is to establish business relations between the government and the private sector, which hopes to increase local revenue (PAD) as well as hand over the affairs of public services which are actually the authority of the government to be authorized by the private sector.

2. In the case of the response of the fishermen of the Kampung Bahar SPBN service users to the quality of services provided, the quality of service in SPBN Kampung Bahari is from aspects; Reliability, Responsiveness, Competence, Courtesy, Understanding, Credibility, Communication and Security are classified as "Good". Whereas in the case of Tangibles and Access, the SPBN service users of Kampung Bahari have diverse opinions due to differences in perceptions of the problem of the condition of the SPBN facilities at Kampung Bahari and the location of the SPBN Kampung existence in the Bengkulu City area.

3. The response of the community to the quality of services organized by SPBN Kampung Bahari is influenced by several things that support the implementation of its services, which include; The capacity of the stakeholders involved, the accuracy of the location, the purchasing power of the community and the awareness of the community as well as the existence of things that hinder the implementation of public services in the SPBN Kampung Bahari which includes: Conditions of service support facilities. Pertamina (Persero) which is less flexible and unfriendly weather conditions in certain months.

\section{Daftar Pustaka}

Basuki, Ananto dan Shofwan. (2006) Penguatan Pemerintahan Desa Berbasis Good Governance. Malang, Sekretariat Penguatan Otonomi Desa (SPOD) FEUB. Deputi2 (2011) Penyerahan Bantuan Beras bagi Para Nelayan di Indramayu. Jakarta. Kementerian

Kordinator Kesejahteraan Rakyat. [internet] Available from <www.menkokesra.go.id/content/penyerahan-bantuan-beras-bagi-para-nelayandiindramayu-0> (Accessed: 17 February 2013).

Dwiyanto, Agus. (2006) Mewujudkan Good Governance melalui Pelayanan Publik. Yogyakarta, Gadjah Mada University Press.

Hasbi, Muhammad. (2010) Aktualisasi Sinergitas Komponen Governance dalam Peningkatan Pelayanan Pendidikan Kecakapan Hidup di Kota Makassar. Universitas Negeri Makassar. Makassar, Artikel program doktoral.

Hashim, Alwi Batubara. (2006) Pelayanan Publik Sebagai Pintu Masuk Dalam Mewujudkan Good Governance. Jurnal Analisis Administrasi dan Kebijakan. Vol.3 No.2, Mei 2006 Hal.3.

Irianti, Ana Frida. (2011) Kemitraan Pemerintah dan Swasta dalam Pengelolaan Pariwisata. Universitas Brawijaya. Malang, Skripsi yang tidak dipublikasikan.

Mahmudi. (2007) Kemitraan Pemerintah Daerah dan Efektivitas Pelayanan Publik. Sinergi, Vol. 9 No. 1, Januari 2007 Hal.55.

Marsiatanti, Dyah Yusi. (2011) Sinergi Antara Pemerintah dan Masyarakat dalam Melestarikan Kesenian Daerah. Universitas Brawijaya. Malang, Skripsi yang tidak dipublikasikan. 
Milles dan Huberman. (1992) Analisis Data Kualitatif. Jakarta, Universitas Indonesia (UIPress). Moleong, J. Lexy. (2004) Metode Penelitian Kualitatif Ed. Revisi. Bandung, PT. Remaja Rosdakarya.

Puspitosari, Hesti, dkk. (2012) Filosofi Pelayanan Publik. Malang. Sastra Press.

Sinambela, Lajian Poltak dkk. (2006) Reformasi Pelayanan Publik, Jakarta. Bumi Aksara.

Sjamsuddin, Sjamsiar. (2006) Kepemerintahan dan Kemitraan. Malang, CV. Sofa Mandiri. Sumarto, Hetifa Sj. (2003) Inovasi, Partisipasi dan Good Governance. Bandung, Yayasan Obor Indonesia.

Tjiptoherijanto, Prijono dan Mandala Manurung. (2010) Paradigma Administrasi Publik dan Perkembangannya. Jakarta, UI Press. 